\title{
MAJOR DEPRESSIVE DISORDER PADA LANSIA (DIBAHAS DENGAN SUDUT PANDANG PSIKOLOGI)
}

\author{
Afdaliza \\ E-mail: afdaliza@lspr.edu \\ LSPR Communication and Business Institute
}

\begin{abstract}
Abstrak
Seiring dengan meningkatnya harapan hidup pada lansia, meningkat pula jumlah penyakit yang ada, salah satunya penyakit mental kronis, yaitu depresi. Depresi bukanlah bagian yang normal dari proses penuaan, namun merupakan masalah yang umum yang terjadi pada lansia. Mereka akan menghadapi banyak duka cita karena kehilangan seseorang yang dicintai atau orang terdekat, menghadapi masa pensiun, kehilangan pekerjaan, perubahan kedudukan, prestise, dan menurunnya kondisi fisik maupun mental. Semua perubahan tersebut sering menimbulkan depresi. Sayangnya, depresi merupakan gangguan yang "bisu", sehingga sulit untuk mendeteksi atau mendiagnosis depresi pada lansia. Banyak lansia dan keluarganya salah meyakini bahwa mereka tidak dapat berbuat apapun terhadap masalah mental dan perilaku, namun jika dilakukan diagnosa, pencegahan, dan treatment yang tepat terhadap depresi, maka lansia bisa hidup lebih lama dan lebih aktif. Terapi yang sering digunakan adalah psikoterapi singkat (sekitar empat bulan) berupa CBT, intervensi obat, dan kombinasi keduanya.
\end{abstract}

Kata Kunci: Major Depressive Disorder, Lansia, Psikologi

\section{PENDAHULUAN}

Selama lebih dari 2000 tahun, depresi telah dikenal sebagai masalah umum. Tidak aneh, depresi dapat disebut sebagai "demam"nya penyakit mental. Depresi merupakan keluhan yang paling biasa terjadi di antara mereka yang mencari perawatan kesehatan mental, dan berada pada urutan ketiga, alasan orangorang datang kepada dokter (Jamil, 2015). Murray \& Lopez (dikutip dalam Alloy, Jacobson, \& Acocella, 1999), berpendapat bahwa sekarang ini Major Depression Disorder (MDD) menduduki posisi keempat sebagai penyebab ketidakmampuan (disability) dan penyebab kematian prematur seseorang (Reddy, 2010). Menurut beberapa para ahli, sekarang ini kita sedang berada pada "zaman depresi". Menurut Kring et al. (2012), selain mempunyai gejala utama kesedihan, yang disertai perasaan apatis, merasa sendiri, depresi juga memiliki gejala psikologis lainnya, yaitu munculnya konsep diri yang negatif, regresif, perubahan aktivitas yang mencakup aspek kognitif, afektif, dan motorik, bahkan kadang-kadang disertai dengan gejala-gejala somatic (Andana, 2017).

Di negara, seperti Amerika Serikat dikatakan bahwa MDD adalah salah satu masalah terbesar kesehatan mental masyarakat (Alloy, Jacobson, \& Acocella, 1999), prevalensi MDD di negara ini setiap bulannya mendekati 4 persen pada pria dan 6 persen pada wanita. Kessler juga dikatakan bahwa pada satu titik 
kehidupan mereka, sekitar 17 persen warga Amerika akan mengalami episode akut depresi, dan sebanyak 6 persen akan mengalami depresi yang lebih kronis (Nolen-Hoeksema, 2002).

Di negara Indonesia sendiri belum dilakukan survei yang pasti dalam mendapatkan jumlah persentase penderita depresi, Richard Budiman (Dokter Spesialis Kesehatan Jiwa, RSJ Dharmawangsa), menyatakan lebih dari 300 juta orang menderita depresi, sementara data WHO menyatakan kasus depresi berdampak pada kalangan usia 20-50 tahun yang berkisar antara 3-8 persen sejak tahun 2005 (Suryanis, 2017). Berdasarkan data di atas, penderita depresi di Indonesia akan meningkat seiring tuntutan kehidupan sosial yang tinggi, perubahan pola kehidupan dengan cepat, beban ekonomi, dan meningkatnya jumlah orang yang berpenyakit kronis.

Depresi dapat terjadi pada tahapan usia perkembangan manapun, termasuk pada orang tua atau lansia. Baik di negaranegara barat maupun di negara berkembang di Asia, Afrika, dan Amerika Latin, depresi pada lansia merupakan masalah penyakit mental yang sangat berkembang pesat (Qonitah \& Isfandiari, 2015). Menurut Perlmutter \& Hall (1992), depresi memang merupakan gangguan fungsional yang paling umum pada individu dewasa akhir, namun dapat disembuhkan. Walaupun dikatakan bahwa depresi merupakan gangguan mental yang umum pada lansia, jika dibandingkan dengan kelompok usia lainnya, sesuai data yang ada, prevalensi MDD pada lansia tergolong rendah.

Evans \& Mottram

(2000)

mengatakan bahwa prevalensi MDD pada lansia hanya mencakup sekitar 1-3\%, walaupun penelitian-penelitian yang ada tidak ikut memperhitungkan komorbiditasnya dengan penyakit fisik dan dementia. Hoyer \& Roodin (2009) mengatakan bahwa terdapat sekitar $4-7 \%$ lansia mengalami depresi secara klinis yang membutuhkan intervensi yang serius (Putri \& Fitriyani, 2016). Terlepas dari jumlah persentase yang ada, Hoyer \& Roodin (2009) mengungkap bahwa depresi bukanlah bagian yang normal dari proses penuaan, namun seperti yang telah disebutkan di atas, depresi merupakan masalah yang umum yang terjadi pada lansia. Proses penuaan pada kenyataannya dapat diasosiasikan dengan perubahan berbagai kondisi kesehatan (termasuk penyakit dan kondisi kronis, penurunan fungsi sensori dan fisiologikal, dan efek samping dari obat-obatan medis), perlambatan kognitif, keterbatasan finansial, dan kehilangan sosial (seperti kematian teman-teman dan anggota 
keluarga). Terkait dengan hal-hal di atas, mudah sekali kita berasumsi bahwa keadaan-keadaan di atas dapat mendorong lansia untuk mengalami depresi.

Walaupun depresi merupakan masalah yang umum, namun merupakan kondisi yang dapat disembuhkan. Sayangnya, sebanyak $80 \%$ lansia yang mengalami MDD tidak menerima treatment sama sekali (Santrock, 2012). Depresi merupakan gangguan yang "bisu", sehingga sulit untuk mendeteksi atau mendiagnosis depresi pada lansia (Sherina, Rampal, \& Kaneson, 2003; Lemme, 2006), hal ini disebabkan karena depresi pada lansia tidak menunjukkan simptom-simptom yang tipikal, seperti kurangnya energi, hilangnya selera makan, mengalami konstipasi, tidak tertarik bekerja, dan kesulitan tidur. Simptom-simptom yang terjadi pada lansia biasanya berupa keluhan fisik dan kognitif. Beberapa alasan mengapa depresi pada lansia cenderung terabaikan, antara lain: (1) lansia cederung terisolasi, hanya beberapa orang yang menyadari tekanan yang mereka alami; (2) dokter atau ahli medis cederung mengabaikan simptom depresi pada lansia, dan hanya terfokus pada keluhan fisik mereka; dan (3) banyak lansia yang depresi yang enggan membicarakan perasaan mereka atau mencari pertolongan (Segal, Pat
Davies, \& Smith, 2007). Berbagai macam alasan inilah, yang membuat gejala-gejala depresi pada lansia jarang terdeteksi, sehingga menutup kemungkinan bagi mereka untuk mendapatkan pertolongan atau intervensi.

Kajian teoretis ini dibuat untuk meningkatkan kesadaran kita sebagai pihak yang bekerja baik di bidang psikologis maupun di bidang medis, yang berhadapan langsung dengan pada lansia yang mengalami depresi. Penting bagi kita untuk menyadari simptom-simptom depresi pada lansia sejak dini, sehingga nantinya depresi lebih mudah untuk disembuhkan.

\section{KAJIAN PUSTAKA}

Menurut DSM-IV-TR, terdapat beberapa ciri pada major depressive episodes. Ciri-ciri utamanya adalah episode tersebut berlangsung dalam kurun waktu setidaknya dua minggu hampir setiap hari, serta mengalami perasaan yang depresi dan kehilangan minat dan kesenangan pada hampir semua aktivitas. Biasanya pada anak-anak dan remaja, perasaan dapat dalam bentuk marah dibandingkan sedih (Mayasari, 2013). Individu juga harus mengalami minimal empat simptom tambahan, yang meliputi perubahan dalam selera makan atau berat badan, tidur, dan aktivitas psikomotorik; berkurangnya energi; perasaan akan tidak 
berharga atau rasa bersalah; kesulitan dalam berpikir, berkonsentrasi, atau mengambil keputusan; atau terus munculnya pikiran akan kematian, atau ide, rencana, ataupun usaha untuk bunuh diri. Episode juga menyebabkan kesulitan atau kerusakan yang signifikan secara klinis pada bidang sosial, pekerjaan, atau bidang-bidang fungsional lainnya yang penting.

Nolen-Hoeksema (2002) juga menambahkan beberapa simptom major depressive episode. Pada beberapa orang yang mengalami depresi, juga mengalami catatonia, yaitu kumpulan perilaku yang tidak biasa, yang dapat berkisar dalam bentuk sama sekali tidak ada gerakan (seperti tetap dalam satu posisi gerakan) sampai agitasi yang menggemparkan tanpa adanya tujuan (seperti terus menggerak-gerakan kaki, tangan). Pada beberapa kasus yang berat, orang yang depresi dapat mengalami delusi dan halusinasi. Delusi merupakan keyakinan tanpa adanya dasar realita, dan halusinasi meliputi melihat, mendengar, atau merasakan sesuatu yang tidak nyata. Delusi dan halusinasi ini biasanya berisikan hal-hal yang depresi dan negatif, misalnya mereka telah berdosa dan pantas dihukum, mereka telah menyakiri orang lain, atau mendengar suara yang memerintahkan mereka untuk bunuh diri.

\section{Pengertian Major Depressive Disorder}

Seseorang yang mengalami satu atau lebih major depressive episodes, tanpa adanya periode mania, dapat dikatakan memiliki Major Depressive Disorder (Alloy, Jacobson, \& Acocella, 1999). Menurut DSM-IV-TR, Ciri-ciri utama MDD dikarakteristikan dengan satu atau lebih major depressive episodes, tanpa adanya sejarah episode manic, mixed, ataupun hypomanic. Episodeepisode penggunaan substansi yang mempengaruhi mood disorder (yang merupakan efek fisik langsung dari drug abuse, pengkonsumsian obat medis, atau toxin exposure) atau mood disorder karena kondisi umum medis tidak diperhitungkan sebagai diagnosis MDD (Hadi, Fitriwijayati, Devianty, \& Rosyanti, 2017). Sebagai tambahan, major depressive episodes bukan karena Schizoaffective Disorder, dan bukan bagian simptom dari Schizophrenia, Schizophreniform Disorder, Delusional Disorder, atau Psychotic Disorder Not Otherwise Specified (The National Council, 2018).

\section{Course Pada Major Depressive Disorder}

Menurut DSM-IV-TR course pada MDD secara umum ada dua macam, yaitu, Single Episode (digunakan hanya untuk episode pertama), atau Recurrent Episodes. Terkadang sulit untuk 
membedakan berlangsungnya satu episode, dengan berlangsung dua episode. sebagai bantuan, satu episode dianggap telah selesai jika kriteria major depressive episode secara keseluruhan tidak terjadi lagi selama dua bulan berturut-turut. Untuk course pada MDD, Recurrent, bervariasi. Ada beberapa orang yang terisolasi episode-episode yang dipisahkan dalam kurun waktu beberapa tahun tanpa adanya simptom-simptom depresi, ada beberapa orang yang memiliki clusters of episodes, dan beberapa yang masih terus mengalami peningkatan frekuensi episode seiring dengan bertambahnya usia mereka. Umumnya, jumlah episode yang mendahului dapat memprediksikan besarnya kemungkinan berkembangnya major depressive episode selanjutnya. Setidaknya sebesar $60 \%$ individu yang mengalami MDD, single episode akan mengalami episode yang kedua. Individu yang telah memiliki dua episode sebelumnya, memiliki persentase $70 \%$ untuk mengalami episode yang ketiga, dan individu yang telah memiliki tiga episode sebelumnya, memiliki persentase $90 \%$ untuk mengalami episode yang keempat (Hadi, Fitriwijayati, Devianty, \& Rosyanti, 2017).

Menurut DSM-IV-TR, MDD dapat disembuhkan dengan sempurna (sekitar 2/3 dari jumlah kasus), atau sembuh sebagian, atau tidak sembuh sama sekali (sekitar 1/3 dari jumlah kasus). Menurut Coryell, Schefner, Keller, beberapa dari mereka yang sembuh masih menunjukan kerusakan yang serius pada status pekerjaan, pendapatan, penyesuaian dalam pernikahan, hubungan sosial, dan aktivitas rekreasi (Alloy, Jacobson, \& Acocella, 1999), sehingga dalam hal ini, bukanlah hal yang mengejutkan, bahwa semakin lama episode terjadi, semakin kecil kemungkinan seseorang untuk sembuh dari depresi.

\section{Effect of Major Depressive Disorder}

Secara umum, semakin berat depresi yang diderita, semakin intensif efek-efek yang dialaminya. Pertama, ketidakbahagiaan dan ketidak-efisiensian. Individu yang mengalami depresi sering merasa "blue", tidak memiliki harapan, sering mengkritik diri sendiri, dan merasa kacau. Sebagai hasil mereka merasa kurang antusias, adalah mereka merasa bimbang, dan terkadang tidak memiliki energi bahkan untuk melakukan hal yang sederhana sekalipun. Kedua, masked reactions. Depresi biasanya merupakan gangguan yang tidak kentara dan tersembunyi, bahkan dari penderita sekalipun, sehingga depresi ini muncul dalam bentuk lain seperti simptom dan kelukan fisik. Ketiga, menarik diri. Saat seseorang merasa tidak bersemangat, tidak 
memiliki motivasi, bosan dengan kehidupan, dan kurangnya percaya diri, sering sekali muncul keinginan dalam dirinya untuk lari dari orang lain (di mana kontak sosial terasa membebani). Keempat, bunuh diri. Bunuh diri dan usaha melakukan bunuh diri biasanya sering terjadi pada remaja, mereka yang hidup sendiri, mereka yang tidak menikah (khususnya mereka yang telah bercerai), dan mereka yang mengalami depresi. Tentu saja, tidak semua orang depresi mencoba untuk bunuh diri, namun banyak yang melakukannya, biasanya dalam bentuk usaha yang dengan sungguhsungguh membunuh diri mereka sendiri dan melarikan diri dari kehidupan (Collins, dikutip dalam Tairas, 2004).

\section{Comorbidity Pada Major Depressive}

\section{Disorder}

Menurut DSM-IV-TR, MDD diasosiasikan dengan tingginya tingkat kematian. Sekitar $15 \%$ individu yang menderita MDD meninggal karena bunuh diri. Bukti Epidemiological juga menunjukkan bahwa terdapat peningkatan sebanyak empat kali lipat tingkat kematian pada individu yang menderita MDD yang berusia lebih dari 55 tahun. Di samping diasosiasikannya dengan tingginya tingkat kematian, MDD juga sering terjadi bersamaan (atau diasosiasikan) dengan gangguan mental lainnya, seperti gangguan yang behubungan dengan substansi, Panic Disorder, Obsessive-Compulsive Disorder, Anorexia Nervosa, Borderline Personality Disorder. MDD biasanya didahului oleh Dysthymic Disorder (10\% dari data Epidemiological, dan 15\%-25\% daru sample klinis). Juga diperkirakan setiap tahunnya sekitar $10 \%$ individu dengan Dysthymic Disorder akan mengalami major depressive episode pertamanya. Menurut Nolen-Hoeksema (2001), terdapat perbedaan antara MDD dan Dysthymic Disorder, yaitu jumlah simptom yang dibutuhkan untuk membuat diagnose, dan durasi gangguan (Tamilselvan, 2015). Perbedaan dapat dilihat pada tabel 1 .

Tabel 1. Perbedaan MDD dan Dysthymic Disorder

\begin{tabular}{llrl}
\hline & MDD & & $\begin{array}{l}\text { Dysthymic } \\
\text { Disorder }\end{array}$ \\
\hline $\begin{array}{l}\text { Jumlah } \\
\text { simptom }\end{array}$ & 5 atau lebih, & 3 atau \\
yang & $\begin{array}{l}\text { termasuk perasaan } \\
\text { depresi, }\end{array}$ & $\begin{array}{r}\text { atau } \\
\text { dibutuhkan, } \\
\text { hilangnya minat } \\
\text { atau rasa senang } \\
\text { (more severe). }\end{array}$ & $\begin{array}{l}\text { perasaan } \\
\text { depresi }\end{array}$ \\
Durasi & $\begin{array}{l}\text { Setidaknya } \\
\text { minggu }\end{array}$ & 2 & $\begin{array}{l}\text { Setidaknya } \\
2 \text { tahun } \\
\end{array}$ \\
& & & $\begin{array}{l}\text { (more } \\
\text { chronic) }\end{array}$ \\
\hline
\end{tabular}

Prevalensi pada Major Depressive Disorder Beberapa kelompok di dalam populasi cenderung rentan dibandingkan kelompok lainnya untuk mengalami MDD (Alloy, Jacobson, \& Acocella, 1999). Kelompok orang yang telah berpisah dan bercerai cenderung rentan mengalami MDD dibandingkan mereka yang 
menikah. Mereka yang cenderung melakukan ruminative coping style lebih rentan mengalami MDD (Lemme, 2006). Ruminative coping style adalah pikiran dan perilaku yang terus berulang-ulang terfokus pada simptom-simptom kesulitan yang dialaminya, misalnya individu yang hanya duduk di rumah dan terus memikirkan betapa kacaunya hidup yang dimilikinya. MDD juga lebih rentan dialami pada mereka yang memiliki anggota keluarga yang juga mengalami MDD (Michl, McLaughlin, Shepherd, \& Nolen-Hoeksema, 2013).

Menurut DSM-IV-TR, MDD 1.5-3 kali lipat lebih mungkin dialami oleh individu yang memiliki sejarah anggota keluarga (yang hanya berbeda satu generasi) yang juga mengalami MDD, jika dibandingkan dengan populasi umum. Nolen-Hoeksema (2002), menyatakan bahwa kebanyakan penelitian juga menunjukkan bahwa wanita dua kali lipat lebih mungkin mengalami simptomsimptom mild depressive dan severe depressive jika dibandingkan dengan pria. Menariknya, pada anak-anak tidak menunjukkan adanya perbedaan gender dalam tingkat depresi. Baru kemudian pada sekitar usia 14 atau 15 tahun, remaja perempuan mulai menunjukkan peningkatan yang tajam pada tingkat depresi, di mana remaja laki-laki tetap memiliki tingkat depresi yang stabil.

Terkait dengan faktor usia, depresi dapat menyerang individu dari semua kelompok usia(Alloy, Jacobson, \& Acocella, 1999). Pada kelompok usia dewasa, individu dengan usia 15-24 tahun lebih rentan mengalami MDD. kelompok usia 45-54 tahun memiliki tingkat depresi yang paling rendah, dan kemudian akan meningkat kembali pada usia 65 tahun ke atas (Nolen-Hoeksema, 2002; Lemme, 2006). Di samping tingkat depresi, juga terdapat perbedaan pada bentuk-bentuk simptom berdasarkan kelompok usia. Pada bayi yang depresi, tanda yang paling terlihat adalah kesulitan untuk makan (Alloy, Jacobson, \& Acocella, 1999). Menurut DSM-IV-TR, pada anak-anak, simptom yang terlihat adalah komplain somatis, marah-marah, dan menarik diri dari lingkungan sosial. Selain itu, episode depresi yang dialami juga disertai dengan gangguan mental lainnya, seperti Disruptive Behavior Disorder, AttentionDeficit Disorder, dan Anxiety Disorder (Sulistyorini \& Sabarisman, 2017). Pada remaja yang mengalami masa pubertas, simptom-simptom juga disertai dengan gangguan mental lainnya, seperti Disruptive Behavior Disorder, AttentionDeficit Disorder, Anxiety Disorder, Substance-Related Disorder, dan Eating 
Disorder. Pada remaja dan dewasa, simptom-simptom dapat juga terjadi dalam bentuk perlambatan motorik, hypersomnia, dan delusi. Pada dewasa akhir, simptom dapat terjadi dalam bentuk simptom kognitif.

\section{METODOLOGI PENELITIAN}

Penelitian ini merupakan penelitian non kausalitas yang bertujuan untuk membandingkan beberapa situasi sehingga mengetahui perbedaan situasi yang berbeda dapat memprediksi faktorfaktor penyebab perbedaan. Situasi penelitian komparatif non-kausalitas dapat dilakukan dengan membandingkan berbagai peristiwa (Supranto \& Limakrisna, 2019, hal. 3). Penelitian ini tidak merumuskan framework penelitian, yang bertujuan memecahkan atau mencari alternatif ke dalam struktur sistem, lingkungan, dan batasannya dalam proses dan merancang model pengambilan keputusan (Husain, 2019). Teknik analisis data dilakukan dengan menganalisis data penelitian dari sudut pandang psikologis dalam penelitian ini untuk menarik kesimpulan tentang hasil penelitian. Analisis data memverifikasi aktivitas penting dari Major Depression Disorder berupa prevalensi MDD, penyebab dan faktor-faktor berisiko yang mendorong depresi pada Lansia, simptom-simptom
MDD, MDD pada lansia dan bunuh diri serta Treatment MDD pada Lansia.

\section{HASIL PENELITIAN}

\section{Major Depression Disorder pada Lansia}

Prevalensi MDD pada Lansia

Terdapat peningkatan yang cukup tajam dalam jumlah lansia pada populasi dunia, baik pada negara maju maupun negara berkembang di abad ke-20 (Sherina, Rampal, \& Kaneson, 2003). Sebagai hasil berkurangnya jumlah kematian dan kelahiran, di mana lebih sedikit anak yang lahir dan semakin banyak orang yang mencapai usia tua, diperkirakan terdapat kurang lebih 580 juta lansia (usia 60 tahun ke atas) di dunia ini, sekitar 335 juta hidup di negara berkembang. Sekarang ini, harapan hidup di lebih dari 20 negara berkembang ada 72 tahun ke atas.

Seiring dengan meningkatnya harapan hidup, meningkat pula jumlah penyakit yang ada, salah satunya penyakit mental kronis, yaitu depresi (Qonitah \& Isfandiari, 2015). Menurut Greist \&, sekitar $10 \%$ orang-orang lansia menderita depresi dan rasa kehilangan merupakan gejala utama pada lansia. Mereka akan menghadapi banyak duka cita karena kehilangan seseorang yang dicintai atau orang terdekat, misalnya kematian pasangan, anggota keluarga, atau kawan dekat (Saputri \& Indrawati, 2011). Belum 
lagi mereka harus menghadapi masa pensiun, kehilangan pekerjaan, perubahan kedudukan, prestise yang akhirnya memunculkan post power syndrome, menurunnya kondisi fisik maupun mental. Menurut Hawari (2007), semua perubahan tersebut sering menimbulkan gangguan emosional berupa kecemasan dan depresi yang disertai pula dengan gangguan fisik tubuh atau depresi terselubung (Tegawati, Karini, \& Agustin, 2009).

Berdasarkan tingkat self-reported simptom-simptom depresi cenderung menunjukkan data dengan pola kurvalinear, di mana tingkat terendah pada kelompok usia dewasa tengah, dan akan terus meningkat sampai di usia yang sangat tua (Gatz, 2001). Menurut Hartati dan Andayani (2004), pada lansia, persentase jumlah penderita depresi meningkat secara tetap sampai usia 80 tahun. Gatz (2001), munculnya depresi yang dilaporkan lansia cukup bervariasi sejak digunakannya metodologi, sampel, kebangsaan, dan kriteria yang berbeda pada berbagai penelitian (Hoyer \& Roodin, 2009). Terdapat data yang menunjukkan bahwa sekitar 4-7\% lansia mengalami depresi secara klinis yang membutuhkan intervensi yang serius. Munculnya depresi pada lansia yang bertempat tinggal di rumah berkisar 1-4\%, berjumlah paling rendah di antara kelompok usia lainnya, sekitar 15-20\% pada pasien rawat jalan, $30 \%$ pada pasien rawat inap, dan $40 \%$ pada penghuni panti werda (Hoyer \& Roodin, 2009).

Sepanjang masa kehidupan, Joiner menyatakan bahwa depresi klinis mempengaruhi wanita dua kali lipat dibandingkan pria, namun pada lansia, baik pria maupun wanita memiliki tingkat depresi yang sama (Hoyer \& Roodin, 2009) . Santrock (2012) mengatakan bahwa hal tersebut karena pria harus berhenti dari pekerjaannya dan pensiun, sehingga menyebabkan mereka berhenti terlibat aktif dengan dunia pekerjaan. Di samping itu, Hoyer \& Roodin (2009) menunjukkan bahwa wanita yang memiliki tingkat penghasilan, kesejahteraan, dan pendidikan yang rendah, serta merupakan anggota rasa tau etnik yang minoritas, memiliki resiko yang tinggi untuk mengalami depresi.

Jika dibandingkan dengan kelompok usia lainnya, sesuai data yang ada, Gatz (2011), prevalensi MDD pada lansia tergolong rendah (Papalia, Olds, \& Feldman, 2010). Hal ini tampaknya terkait dengan alasan bahwa depresi pada lansia lebih sulit didiagnosa dibandingkan dengan orang muda (Lemme, 2006). Menurut Hoyer \& Roodin (2009), terdapat beberapa alasan mengapa depresi pada lansia lebih sulit untuk didiagnosa. 
Pertama, manifestasi depresi pada lansia berbeda dengan orang muda. Mereka memiliki pola simptom depresi yang disebut depletion syndrome. Sindrom ini dikarakteristikan dengan kurangnya minat, tidak memiliki harapan, dan perasaan bahwa segalanya membutuhkan usaha yang sangat besar. Kedua, baik lansia maupun anggota keluarganya meyakini bahwa depresi merupakan bagian konsekuensi dari bertambah tua, merefleksikan akumulasi kehilangan pribadi (pasangan, pekerjaan, teman, keluarga, dan rumah) dan masalah kesehatan. Ketiga, lansia mungkin tidak memiliki strategi asesmen diri yang baik, sehingga mereka tidak menyadari keberadaan depresi itu sendiri. Kebanyakan lansia melaporkan perasaan negatif ke anggota keluarga dan dokter dengan istilah yang berbeda, yang mengekspresikan (1) keluhan kognitif, seperti merasa tidak berharga, kacau, tidak punya harapan, dan demoralisasi; dan (2) keluhan somatisasi, seperti kesulitan tidur, tidak bertenaga, menurunnya berat badan, gangguan usus, menurunnya selera makan, sakit, dan gugup. Keempat, para ahli klinis merasa sulit mendiagnosa depresi pada lansia dengan menggunakan kriteria DSM. Banyaknya keluhan somatisasi dianggap bias, padahal keluhan tersebut banyak disampaikan oleh lansia.
Kelima, banyak lansia yang merasa malu mencari pertolongan treatment, dan enggan mengakuinya sebagai kesulitan pribadi karena merasa malu, bersalah, dan takut ketahuan oleh publik. Sayangnya, depresi yang tidak di-treatment inilah yang menempatkan lansia berada pada urutan tertinggi yang paling beresiko bunuh diri dibandingkan orang muda.

Penyebab dan Faktor-faktor Berisiko yang Mendorong Depresi pada Lansia

Menurut Jefferson \& Greist, kerentanan seseorang terhadap derpesi merupakan hasil interaksi dari genetik dengan faktor lingkungan. Kejadiankejadian yang membuat tertekan, kesepian, dan penggunaan medikasi tertentu dapat mendorong terjadinya depresi (Papalia, Olds, \& Feldman, 2010). Brain imaging pada pasien depresi menunjukkan ketidak-seimbangan neurotransmitter dan malfungsi system syaraf dalam hal pengaturan mood, berpikir, tidur, selera makan, dan perilaku.

$$
\text { Perlmutter \& Hall }
$$
berpendapat bahwa penyebab depresi sering sulit untuk ditemukan. Kehilangan seseorang atau sesuatu yang penting, sering mendahului terjadinya depresi. Kekecewaan yang mendalam, kritikan, ancaman baik yang nyata maupun yang hanya merupakan imajiner, biasanya dapat melatarbelakangi depresi. Pada saat rasa 
bersalah muncul pada diri seseorang, biasanya perasaan tersebut berasal dari keyakinan bahwa dirinya telah gagal memenuhi tugas kehidupannya.

Evans \& Mottran (2000), menunjukkan bahwa terdapat beberapa faktor yang biasanya dihubungkan dengan munculnya depresi pada diri seseorang, dan dapat digunakan untuk mengidentifikasikan kelompok-kelompok yang beresiko tinggi mengalami depresi. Faktor-faktor tersebut antara lain (1) penyakit fisik, khususnya penyakit yang menyakitkan atau membuat dirinya tidak mampu; (2) merasa kesepian (dan tidak tinggal sendirian); (3) baru saja mengalami perasaan duka cita atau kejadian-kejadian lainnya yang merugikan; (4) kesulitan-kesulitan mendengar, (5) memiliki sejarah depresi, baik pada dirinya maupun anggota keluarga; (6) dementia, atau gangguan kognitif lainnya yang menahan pengetahuan; (7) penggunaan medikasi (seperti steroids, major tranquillizers); dan (8) berjenis kelamin wanita (dengan perbandingan wanita : pria $=70: 30$ ) (Haryanto, Wahyuningsih, \& Nandiroh, 2015).

Penyakit fisik merupakan satu dari sekian faktor kuat terhadap depresi (Hoyer \& Roodin, 2009). Gatz (2001) mengatakan bahwa buruknya kesehatan merupakan pengalaman hidup yang membuat tertekan dan dengan demikian dapat menstimulasi depresi, baik secara langsung, maupun melalu keterbatasan fungsional atau rasa sakit. Hubungan antara depresi dan kesehatan, tampkanya merupakan hubungan bidireksional. Penyakit fisik (atau penggunaan medikasi) dapat memimbulkan perubahan biologis sehingga dapat menorong munculnya depresi. Sebaliknya, depresi juga dapat menyebabkan penyakit fisik, bahkan kematian. Keterkaitan depresi dengan penyakit fisik tentunya juga terjadi pada semua kelompok usia, hanya saja keterkaitan ini lebih difokuskan pada lansia, karena lansia lebih sering mengalami penyakit dan keterbatasan fisik. Deeg, et.al, menyatakan bahwa terdapat satu hal yang perlu diperhatikan bahwa bagi lansia yang mampu menghadapi dan menerima penyakit fisik kronisnya dengan baik, lebih kecil kemungkinannya mengalami depresi klinis (Hoyer \& Roodin, 2009).

\section{Simptom-Simptom MDD pada Lansia}

Menurut Evans \& Mottran (2000), terdapat beberapa simptom MDD pada lansia, antara lain (1) dysphoria, biasanya berupa keluhan sulit sembuh, cemas, marah, gangguan tidur dan selera makan, hilangnya tenaga, somatisasi, dan kehilangan minat terhadap aktivitas 
sehari-hari; (2) sering menangis, dan lebih banyak terjadi pada wanita; (3) kecemasan dan agitasi, biasanya hal ini diasosiasikan karena rendahnya self-esteem, dan ketidakmampuan untuk coping; (4) kurangnya energi dan kelelahan; (5) perlambatan fisik, yang dapat meningkatkan kesulitan coping terhadap aktivitas sehari-hari, diet yang buruk, dan berhentinya makan dan minum; (6) defisit kognitif, biasanya berupa berkurangnya kemampuan bahasa dan proses memori, serta menurunnya motivasi secara drastis; (7) somatisasi; (8) hypochondriasis, yaitu ketakutan yang berlebihan mengidap penyakit; (9) perasaan akan memiliki hidup yang tidak berharga dan ingin mati; dan (10) gangguan perilaku, biasanya terjadi pada lansia yang depresi terhadap pengasuh, dapat berupa menolak makanan, buang air kecil dan besar sembarangan, pura-pura jatuh, atau bahkan melakukan kekerasan seperti menggigit dan mencakar (Nuryati \& Kresnowati, 2018; Budisetyani, Widiasavitri, Marheni, Tobing, \& Astiti, 2016).

\section{MDD pada Lansia dan Bunuh Diri}

Depresi yang tidak terdiagnosa dan yang tidak di-treatment merupakan faktor resiko yang mendorong terjadinya bunuh diri untuk semua kelompok usia (Hoyer \& Roodin, 2009). Pada lansia, kasus bunuh diri sebagai tindak lanjut depresi ternyata cukup tinggi dibandingkan kelompok usia lainnya (Lemme, 2006).

Penelitian-penelitain berpendapat bahwa 90\% dari kasus bunuh diri pada lansia, diasosiasikan dengan gangguan mental, dan dua per tiganya yaitu MDD, dan pada eposide pertama. Pada penelitian yang dilakukan, Zweig \& Hinrichsen menemukan bahwa resiko tinggi untuk melakukan usaha bunuh diri berada pada mereka yang memiliki tingkat sosialekonomi yang tinggi, memiliki sejarah pernah melakukan usaha bunuh diri, dan mengalami stressor interpersonal, seperti ketegangan dengan pasangan, atau anakanaknya yang telah dewasa (Lemme, 2006).

Faktor-faktor resiko lainnya yang juga mendorong lansia melakukan bunuh diri adalah gender, tinggal sendiri, isolasi sosial, kehilangan atau kematian pasangan hidup, dan memburuknya kesehatan. Untuk pria yang berusia 65 tahun ke atas, bunuh diri merupakan penyebab ketiga pada kematian, khususnya pada pria yang tinggal sendiri, kehilangan istrinya, dan mengalami kemunduran kesehatan (Hoyer \& Roodin, 2009; Santrock, 2012).

Treatment MDD pada Lansia

Banyak lansia dan keluarganya salah meyakini bahwa mereka tidak dapat berbuat apapun terhadap masalah mental 
dan perilaku, namun jika dilakukan diagnosa, pencegahan, dan treatment yang tepat terhadap depresi, maka lansia bisa hidup lebih lama dan lebih aktif (Penninx, et.al, dikutip dalam Papalia, et. al, 2007). Bahkan treatment yang sukses dapat memberikan banyak keuntungan seperti meningkatkan kualitas hidup, mengurangi penyakit fisik dan biaya kesehatan, dan meningkatkan produktivitas serta kemampuan untuk bertahan hidup (Lemme, 2006).

Intervensi-intervensi psikoterapi pada depresi lansia dapat berupa (a) cognitive and behavioral therapy (CBT); dan (b) terapi brief psychodynamic, interpersonal, dan life-review. Semua treatment tersebut dapat dilakukan secara individu maupun kelompok (Gatz, 2001). Menurut Hoyer \& Roodin (2009), terapi yang sering digunakan adalah psikoterapi singkat (sekitar empat bulan) berupa CBT, intervensi obat, dan kombinasi keduanya.

Terapi obat pada depresi lansia berupa obat antidepressant, seperti Prozac. Obat tersebut tidak hanya dapat mengurangi simptom depresi, namun juga memperbaiki gangguan kognitif. Namun demikian, kemampuan kognitif seperti memori dan penilaian personal tidak mengalami perbaikan. Penelitanpenelitian menyatakan bahwa terapi yang paling sukses adalah CBT, dan kombinasi antara CBT dengan intervensi obat. Untuk terapi obat sendiri menunjukkan kemajuan yang paling sedikit (Hoyer \& Roodin, 2009). Terapi untuk depresi sering didasarkan pada pendekatan cognitive and behavioral, dan intervensi brief psychotherapeutic (Hoyer \& Roodin, 2009). CBT berusaha untuk merubah pikiran, keyakinan, dan sikap yang negatif yang ada pada diri individu depresif terhadap diri mereka sendiri, pengalaman dan masa depan mereka. Sekalinya mereka mengembangkan pola piker yang lebih fleksibel, pasien akan mengalami peningkatan dalam emosional, sehingga dapat mengurangi depresi dan meningkatkan fungsi dalam kehidupan sehari-hari. Depresi juga dapat menyebabkan perilaku menarik diri. Dengan terus menerus melakukannya akan membuat seseorang merasa buruk dan semakin buruk. CBT mencoba untuk mematahkan lingkaran tersebut dan mendorong pasien berpatisipasi dalam aktivitas sehari-hari. Dengan ikut melakukan aktivitas yang menyenangkan dapat meningkatkan mood dan perasaan, sehingga dengan demikian mengurangi depresi. Bahkan pada pasien depresi yang memiliki penyakit kronis sekalipun dapat menggunakan teknik terapi ini.

Program-program psikoedukasional yang mengkombinasikan terapi kelompok dan 
edukasi juga merupakan bentuk treatment depresi pada lansia (Hoyer \& Roodin, 2009). Program-program tersebut memiliki kurikulum spesifik yang memberikan informasi-informasi penting, serta memberikan partisipan kesempatan untuk mendiskusikan masalah-masalah mereka. Di samping semua treatment yang telah disebutkan di atas, adanya dukungan sosial dan merasa teritegrasi dengan komunitas juga membantu mengurangi depresi pada lansia (Santrock, 2012). Hal ini bisa juga disebut dengan Stress-buffering effects, yaitu efek dukungan sosial dari orang-orang yang dicintai di keluarga, teman-teman terdekat, serta orang-orang di masyarakat dan organisasi (Hoyer \& Roodin, 2009). Dukungan sosial dapat mencegah pengaruh faktor-faktor yang beresiko tinggi terhadap depresi dan meningkatkan kemampuan coping terhadap kejadiankejadian negatif dalam hidup.

\section{KESIMPULAN}

Depresi merupakan proses patologis pada semua kelompok usia. Depresi dapat terjadi melalui berbagai bentuk simptom pada lansia. Simptom-simptom derpresi yang biasa terjadi pada lansia antara lain dysphoria, sering menangis, kecemasan dan agitasi, kurangnya energi dan kelelahan, perlambatan fisik, defisit kognitif, somatisasi, hypochondriasis, perasaan akan memiliki hidup yang tidak berharga dan ingin mati, dan gangguan perilaku.

Depresi bukanlah bagian yang normal dari proses penuaan, namun demikian, tampaknya depresi merupakan masalah yang umum yang terjadi pada lansia. Mereka akan menghadapi banyak duka cita karena kehilangan seseorang yang dicintai atau orang terdekat, misalnya kematian pasangan, anggota keluarga, atau kawan dekat. Belum lagi mereka harus menghadapi masa pensiun, kehilangan pekerjaan, perubahan kedudukan, prestise yang akhirnya memunculkan post power syndrome, menurunnya kondisi fisik maupun mental. Semua perubahan tersebut sering menimbulkan depresi.

Berdasarkan penelitian-penelitan yang telah dilakukan mengatakan bahwa terdapat sekitar $4-7 \%$ lansia mengalami depresi secara klinis yang membutuhkan intervensi yang serius. Jika dilihat jumlah persentasenya, memang bukan merupakan angka yang besar,namun jika tidak ditindak lanjuti, akan menjadi masalah yang besar seperti munculnya penyakit fisik maupun mental, bahkan dapat sampai mengarah pada kematian dan bunuh diri.

Depresi pada lansia sering kurang disadari, baik oleh individu sendiri, maupun oleh orang-orang di sekitarnya 
dan dokter. Depresi sering sekali dianggap sebagai reaksi yang wajar pada lansia yang memiliki penyakit fisik atau lansia yang baru saja kehilangan seseorang atau sesuatu. Adanya somatisasi, gangguan komunikasi, dan gangguan lainnya sering menambah kesulitan untuk mengidentifikasi depresi pada lansia. Para lansia mungkin saja enggan untuk membicarakan perasaan mereka atau mencari pertolongan, sehingga butuh dilakukannya evaluasi secara berkala. Keluarga dan pengasuh (baik di panti werda maupun di rumah sakit) cenderung enggan untuk mempertanyakan topik yang sensitif secara emosional. Berbagai macam alasan inilah yang membuat gejala-gejala depresi pada lansia jarang terdeteksi, sehingga menutup kemungkinan bagi mereka untuk mendapatkan pertolongan atau intervensi.

Banyak lansia dan keluarganya salah meyakini bahwa mereka tidak dapat berbuat apapun terhadap masalah mental dan perilaku, namun perlu untuk diketahui bahwa treatment untuk depresi tersedia. Jika dilakukan diagnosa, pencegahan, dan treatment yang tepat terhadap depresi dapat memberikan banyak keuntungan seperti meningkatkan kualitas hidup, mengurangi penyakit fisik dan biaya kesehatan, dan meningkatkan produktivitas serta kemampuan untuk bertahan hidup.

Treatment yang dapat dan sering digunakan adalah psikoterapi singkat (sekitar empat bulan) berupa CBT, intervensi obat,antidepressant, kombinasi keduanya, dan program-program psikoedukasional yang mengkombinasikan terapi kelompok dan edukasi.

Penggunaan kombinasi CBT dan intervensi obat biasanya memberikan kemajuan yang paling sukses di antara bentuk treatment lainnya. Selain semua treatment yang ada, adanya dukungan sosial dan merasa teritegrasi dengan komunitas juga membantu mengurangi depresi pada lansia.

\section{DAFTAR PUSTAKA}

Alloy, L. B., Jacobson, N. S., \& Acocella, J. R. (1999). Abnormal Psychology: Current Perspectives (8 ed.). New York: McGraw-Hill.

Andana, P. (2017). Terapi Murattal Untuk Menurunkan Depresi. Program Studi Magister Psikologi Profesi. Yogyakarta: Universitas Mercu Buana.

APA. (2013). Diagnostic and statistical manual of mental disorders (DSM5®) $(5$ ed.). Washington, DC: American Psychiatric Association.

Budisetyani, I. G., Widiasavitri, P. N., Marheni, A., Tobing, D. H., \& Astiti, D. P. (2016). Psikologi Abnormal. Program Studi Psikologi. 
Bali: Fakultas Kedokteran, Universitas Udayana.

Evans, M., \& Mottram, P. (2000). Diagnosis of Depression in Elderly Patients. Advances in Psychiatric Treatment, 6(1), 49-56.

Hadi, I., Fitriwijayati, Devianty, R., \& Rosyanti, L. (2017). Gangguan Depresi Mayor (Mayor Depressive Disorder) Mini Review. Health Information : Jurnal Penelitian, 9(1), 25-40.

Haryanto, Wahyuningsih, H. D., \& Nandiroh, S. (2015). Sistem Deteksi Gangguan Depresi pada Anak-Anak dan Remaja. Jurnal Ilmiah Teknik Industri, 14(2), 142-152.

Hoyer, W. J., \& Roodin, P. A. (2009). Adult Development and Aging: (6 ed., Vol. Learning Resources: BOOK REVIEW). New York: McGraw Hill.

Husain, T. (2019). An Analysis of Modeling Audit Quality Measurement Based on Decision Support Systems (DSS). European Journal of Scientific Exploration, 2(6), 1-9.

Jamil. (2015). Sebab dan Akibat Stres, Depresi dan Kecemasan serta Penanggulangannya. Al Amin: Jurnal Kajian Ilmu dan Budaya Islam, 3(1), 123-138.

Kring, A. M., Johnson, S. L., Davison, G. C., \& Neale, J. M. (2012). Abnormal Psichology (12 ed.). USA: John Wiley \& Sons, Inc.

Lemme, B. H. (2006). Development in Adulthood (4 ed.). Boston: Allyn \& Bacon.
Mayasari, N. N. (2013). Gambaran Umum Depresi. SMF Psikiatri, 2020. Bali: Fakultas Kedokteran Universitas Udayana.

Michl, L. C., McLaughlin, K. A., Shepherd, K., \& Nolen-Hoeksema, S. (2013). Rumination as a Mechanism Linking Stressful Life Events to Symptoms of Depression and Anxiety: Longitudinal Evidence in Early Adolescents and Adults. $J$ Abnorm Psychol, 122(2), 339-352.

Nolen-Hoeksema, S. (2002). Gender differences in depression (Handbook of depression, p.492-509) (In ed.). (I. H. Gotlib, \& C. L. Hammen, Penyunt.) New York: The Guilford Press.

Nuryati, \& Kresnowati, L. (2018). Klasifikasi dan Kodefikasi Penyakit dan Masalah Terkait III: Anatomi, Fisiologi, Patologi, Terminilogi, Medis dan Tindakan pada Sistem Panca Indra, Saraf dan Mental. Jakarta: Kementerian Kesehatan Republik Indonesia.

Papalia, D., Olds, S., \& Feldman, R. (2010). Human Development (Psikologi Perkembangan) (11 ed.). (A. Anwar, Penerj.) Jakarta: Kencana Prenada Media Group.

Putri, S. I., \& Fitriyani, P. (2016). Gambaran Tingkat Depresi Lansia yang Melakukan Senam di Panti Sosial Tresna Werdha di Jakarta. Jurnal Keperawatan Indonesia, 19(2), 92-99.

Qonitah, N., \& Isfandiari, M. A. (2015). Correlation between BMI and ADLs with Mental Emotional Disorder among Elderly. Jurnal Berkala Epidemiologi, 3(1), 1-11. 
Reddy, M. S. (2010). Depression: The Disorder and the Burden. Indian $J$ Psychol Med. , 32 (1), 1-2.

Santrock, J. (2012). Life-Span development:Perkembangan MasaHidup (Jilid 1 \& 2) (13 ed.). Jakarta: Erlangga.

Saputri, M. A., \& Indrawati, E. S. (2011). Hubungan antara Dukungan Sosial dengan Depresi pada Lanjut Usia yang Tinggal di Panti Wreda. Jurnal Psikologi Undip, 9(1), 65-72.

Segal, J. J., Pat Davies, P., \& Smith, M. (2007). Depression in Older Adults and the Elderly. Dipetik Agusuts 2020, dari http://www.helpguide.org/mental/de pressionelderly.htm

Sherina, M. S., Rampal, L., \& Kaneson, N. (2003). Prevalence of emotional disorders among medical students in a Malaysian university. Asia Pacific Family Medicine, 2, 213-217.

Sulistyorini, W., \& Sabarisman, M. (2017). Depresi: Suatu Tinjauan Psikologis. Sosio Informa (Kajian Permasalahan dan Usaha Kesejahteraan Sosial), 3(02), 153164.
Suryanis, A. (2017, Mei 19). Jumlah Penderita Depresi Meningkat dari Tahun ke Tahun. Dipetik Agustus 2020, dari Tempo.co: https://gaya.tempo.co/read/876674/j umlah-penderita-depresi-meningkatdari-tahun-ke-tahun/full\&view $=$ ok

Tamilselvan, S. (2015). Penilaian Keparahan serta Komorbiditas Gangguan Panik. Intisari Sains Medis, 4(1), 42-50.

Tegawati, L. M., Karini, S. M., \& Agustin, R. W. (2009). Pengaruh senam lansia terhadap penurunan tingkat depresi pada orang lanjut usia. Wacana Jurnal Psikologi Universitas Sebelas Maret, 1(2), 3646.

The National Council. (2018, Agustus). Accurate Diagnosis of Primary. Dipetik Agustus 2020, dari The Care Transitions Network: https://www.thenationalcouncil.org/ wpcontent/uploads/2018/08/AccurateDiagnosis-of-Primary-PsychoticDisordersSlides.pdf?daf=375ateTbd56 